\title{
Human telomerase reverse transcriptase as a major therapeutic target in different cancer types
}

\author{
Zorawar Singh* and Priya Khangotra \\ Department of Zoology, Khalsa College Amritsar, Punjab, India
}

\begin{abstract}
Telomerase is a known global therapeutic target in cancer cells. Human telomerase reverse transcriptase (hTERT) is a catalytic subunit of the telomerase enzyme. hTERT is usually silenced in almost all somatic cells but it is significantly expressed in $\sim 90 \%$ of human cancers. Many cancer suppressing genes produce factors that hinder hTERT activity. Here, in this review paper, an attempt has been made to emphasize the role of hTERT in different cancer types. Various recent therapeutic studies involving hTERT suppression have also been discussed. Serum hTERT mRNA levels have been found to reflect the tumour burden and the clinical status of the patient. Nano-formulations like nano-curcumin and nano-chrysin have also been shown to significantly decrease hTERT gene expression in SW480 cells. High frequency of hTERT-promoting mutations and increased expression of hTERT mRNA makes it a suitable target in different cancer types.
\end{abstract}

\section{Introduction}

Telomerase reverse transcriptase (TERT) is a catalytic subunit of the telomerase enzyme and is abbreviated as hTERT in case of humans. Telomerase is known as a global therapeutic target in cancer cells due to its main role in tumorigenesis [1]. Cancer cells achieve proliferative immortality by activating or upregulating the normally silent human TERT gene (hTERT) that encodes telomerase [2]. It has been proved that hTERT is aberrantly methylated in tumour tissue versus healthy counterparts [3]. The degradation of chromosomal ends is prevented by the addition of repetitive DNA sequences. The enzyme telomerase helps to lengthen the telomeres in DNA strands. TERT is liable for catalysing the nucleotide addition in a "TTAGGG" sequence to the ends of chromosomal telomeres. hTERT gene is located on chromosome 5 that consists 16 exons and 15 introns spanning $35 \mathrm{~kb}$. Cri du chat is a rare genetic disorder reported due to absence of hTERT or deletion on chromosome 5. This disorder is also known as chromosome 5psyndrome or Lejeune's syndrome.

Promoter of hTERT is GC-rich and deficit in TATA and CAAT boxes. Recent reports have implicated two cancer-specific hTERT promoter mutations (mainly C-T transitions) in the activation of telomerase in cancer cells [4]. These mutations, which are located either -124 base pairs (bp) or -146 bp upstream from the TERT translation start site have been found to be associated with increased telomerase activity [5]. High frequency of hTERT-promoting mutations and increased expression of hTERT mRNA in anaplastic thyroid cancer (ATC) make TERT a suitable molecular target for its treatment [6]. There are transcription factors that can initiate hTERT which includes many oncogenes and many cancer suppressing genes including p53 and WT1 have been reported to produce factors that hinder hTERT activity. hTERT plays an important role in colorectal cancer growth [7]. Although hTERT is usually silenced in almost all somatic cells but is significantly expressed in $\sim 90 \%$ of human cancers [2] thus confirming that over-expression of hTERT is associated with cancers and tumour formations.

\section{hTERT in different cancer types}

A number of studies were found targeting hTERT in different cancer types. Function and underlying molecular mechanism of MicroRNA - 138 in cervical cancer was investigated and was found that MicroRNA - 138 inhibits proliferation, migration and invasion through targeting hTERT in cervical cancer [8]. Nano-formulations have also been investigated for their efficacy to regulate hTERT expressions. Drug release study was performed using dialysis method and the cytotoxic and inhibitory effects of individual and combined drugs on expression level of hTERT in T47D breast cell line were evaluated using MTT assay and $\mathrm{qPCR}$, respectively. Real-time PCR results revealed that Metformin (Met), Curcumin (Cur) and combination of Met-Cur in free and nano-encapsulated forms inhibited hTERT gene expression [9]. Similarly, a study revealed that Curcumin (Cur) and Chrysin (Chr) and combination of Cur-Chr in free and encapsulated forms inhibited hTERT gene expression [10]. Free and nano-encapsulated Chrysin-Curcumin has also been investigated for inhibition of hTERT gene expression in SW480 colorectal cancer cell line. A significant decrease in hTERT gene expression in SW480 cells that were treated with nano-curcumin and nano-chrysin as compared to untreated cells [11]. Silibinin-loaded magnetic nanoparticles have also been reported to inhibit hTERT gene expression and proliferation of lung cancer cells [12]. hTERT expression seems to promote invasiveness of cancer cells [13]. Resveratrol attenuates norepinephrine-induced ovarian cancer invasiveness through downregulating hTERT expression [14]. Table 1 summarizes various studies reporting the association of hTERT and different cancer types [15-41].

${ }^{\star}$ Correspondence to: Zorawar Singh, Assistant Professor, Department of Zoology, Khalsa College Amritsar, Punjab, India, Tel: +91-94172-30075; E-mail: zorawarsinghs@rediffmail.com

Key words: hTERT, telomerase, hTERT mRNA, tumour, cancer, oncogenes

Received: January 27, 2019; Accepted: February 08, 2019; Published: February 13,2019 
Table 1. Studies reporting the association of hTERT with different cancer types

\begin{tabular}{|c|c|c|c|}
\hline Cancer type & Authors & Year & Reference \\
\hline Breast cancer & Chatran et al. & 2018 & {$[15]$} \\
\hline Breast cancer & Daniel and Tollefsbol & 2018 & {$[16]$} \\
\hline Breast cancer & Rasouli and Zarghami & 2018 & {$[17]$} \\
\hline Breast cancer & Jahanban-Esfahlan et al. & 2017 & {$[18]$} \\
\hline Breast cancer & Thriveni et al. & 2018 & [19] \\
\hline Breast cancer & Farajzadeh et al. & 2018 & [9] \\
\hline Breast cancer & Feng et al. & 2017 & {$[20]$} \\
\hline Breast cancer & Dinami et al. & 2017 & {$[21]$} \\
\hline Breast cancer & Ebrahimnezhad et al. & 2018 & {$[22]$} \\
\hline Breast cancer & Yu et al. & 2018 & {$[23]$} \\
\hline Breast cancer & Aydin et al. & 2018 & {$[24]$} \\
\hline Cervical cancer & Zhou et al. & 2016 & {$[8]$} \\
\hline Cervical cancer & Molano et al. & 2016 & {$[25]$} \\
\hline Cervical cancer & Yang et al. & 2017 & {$[26]$} \\
\hline Gastric cancer & Zhang et al. & 2017 & {$[27]$} \\
\hline Gastric cancer & Zhang et al. & 2018 & {$[28]$} \\
\hline Gastric cancer & Mahfouz et al. & 2017 & {$[29]$} \\
\hline Lung cancer & Ludlow et al. & 2018 & {$[30]$} \\
\hline Lung cancer & Yang et al. & 2017 & {$[31]$} \\
\hline Lung cancer & Amirsaadat et al. & 2017 & {$[12]$} \\
\hline Lung cancer & Sadeghzadeh et al. & 2017 & {$[32]$} \\
\hline Lung cancer & Chen et al. & 2017 & {$[33]$} \\
\hline Lung cancer & Jahanban-Esfahlan et al. & 2017 & {$[18]$} \\
\hline Lung cancer & Lin et al. & 2018 & {$[34]$} \\
\hline Lung cancer & Zalewska-Ziob et al. & 2017 & {$[35]$} \\
\hline Head and neck cancer & Barczak, Sobecka et al. & 2018 & {$[36]$} \\
\hline Head and neck cancer & Sobecka et al. & 2018 & [3] \\
\hline Head and neck cancer & Barczak, Suchorska et al. & 2017 & {$[37]$} \\
\hline Colon cancer & Martin, Kala and Tollefsbol & 2018 & {$[38]$} \\
\hline Bladder cancer & March-Villalba et al. & 2018 & [39] \\
\hline Bladder cancer & Huang et al. & 2017 & {$[40]$} \\
\hline Non-small-cell lung cancer & Ludlow et al. & 2018 & {$[30]$} \\
\hline Non-small-cell lung cancer & Lin et al. & 2018 & [34] \\
\hline Non-small-cell lung cancer & Zalewska-Ziob et al. & 2017 & {$[35]$} \\
\hline Non-small-cell lung cancer & Chen et al. & 2017 & {$[33]$} \\
\hline Thyroid cancer & Lombardo et al. & 2018 & {$[6]$} \\
\hline
\end{tabular}

Bufalin can induce apoptosis in certain human cancer cell lines. Zhang et al. [7] investigated the role and interactions of bufalin, CPSF4 and hTERT and the effects of bufalin in human colorectal cancer. The results revealed that CPSF4 acts as an hTERT promoter-binding protein in colorectal cancer cells. Alternative splicing is dysregulated in cancer and the reactivation of telomerase involves the splicing of TERT transcripts to produce full-length (FL) TERT. A study by Ludlow et al. [30] identified splicing factors that reduced telomerase activity and shortened telomeres. NOVA1, when knocked down resulted in a shift in hTERT splicing to non-catalytic isoforms, reduced telomerase activity, and progressive telomere shortening. Similarly, ZEB1 stimulates the growth and was found to be positively correlated with hTERT expression in breast invasive ductal carcinoma samples at both the mRNA and protein levels [23]. This study revealed a new ZEB1hTERT signalling pathway involved in regulation of cell proliferation in breast cancer. Melissa officinalis extract (MOE) elicits potent antiproliferative effects on different human cancer cells. MOE has been reported to result in a significant downregulation of hTERT ( 0.023 fold) compared to the untreated control [18]. It was further suggested that the potent anti-proliferative activity of the hydro-alcoholic extract of Melissa officinalis is somehow explainable by its high potency to inhibit expression of the prominent oncogenes Bcl2, Her2, VEGF-A and hTERT in prostate cancer.
Likewise, the mechanistic investigation showed that the tumour-promoting role of Bromodomain PHD finger transcription factor (BPTF) in hepatocellular carcinoma (HCC) was realized by transcriptionally regulating the expression of hTERT. Furthermore, it was found that patients with high BPTF expression displayed high hTERT expression. High BPTF or hTERT expression levels were positively correlated with advanced malignancy and poor prognosis in HCC patients [42]. Another research study explored the relationship between quantitative mRNA determination (hTERT) in patients with bladder tumour, history of bladder tumour, and in subjects without a history of this neoplasia. Differences were observed in mean hTERTN levels in each of the groups: tumour presence $21.33 \pm 40.66$, tumour history $2.16 \pm 2.67$ and controls $0.9 \pm 1.75(\mathrm{p}<0.001)$. In patients with tumour, there was no difference in mean hTERTN levels between the different grades and stages. Thus, hTERTN mRNA levels in urine were higher in patients with bladder tumours compared to patients with a history of bladder tumour and with negative cystoscopy, as well as in the control group presenting hTERTN as a useful biomarker in bladder tumours [39]. Serum hTERT mRNA levels may reflect the tumour burden and the clinical status of the patient. A study evaluated the feasibility of the detection of hTERT transcripts in serum. hTERT mRNA levels were determined in serum and serum-derived exosomes from 133 patients with different malignancies and 45 healthy controls. 
hTERT transcript was absent in all controls and was variably detected in $67.5 \%$ of patients with all cancer types. A correlation between hTERT transcript levels and the clinical course was found in several cases evidencing that mRNA levels may reflect the tumour burden [43].

\section{Conclusion}

Human telomerase reverse transcriptase (hTERT), a catalytic subunit of the telomerase enzyme and is significantly expressed in $\sim 90 \%$ of human cancers. In the present review paper, a number of studies were found reporting the association of hTERT with different cancer types. A large number of studies were found reporting the role of hTERT in breast and lung cancers. Now a days, hTERT has been taken as a useful therapeutic target in different studies to cope up with the menace of cancer. Many studies were found putting up different moieties to significantly decrease hTERT gene expression including MicroRNA-138, metformin, curcumin, chrysin and extracts of Melissa officinalis extracts and Silibinin-loaded magnetic nanoparticles. Conclusively, downregulation of hTERT expression should be the prime focus of the future studies so as to put forward new strategies to control tumorigenesis.

\section{Conflicts of interest}

None declared.

\section{References}

1. Bagheri R, Sanaat Z, Zarghami N (2018) Correction: Synergistic effect of free and nano-encapsulated chrysin-curcumin on inhibition of hTERT gene expression in SW480 colorectal cancer cell line. Drug Res.

2. Jafri MA, Ansari SA, Alqahtani MH, Shay JW (2016) Roles of telomeres and telomerase in cancer, and advances in telomerase-targeted therapies. Genome Med 8: 69. [Crossref]

3. Sobecka A, Blaszczak W, Barczak W, Golusinski P, Rubis B, et al. (2018) hTERT promoter methylation status in peripheral blood leukocytes as a molecular marker of head and neck cancer progression. J Appl Genet 59: 453-461. [Crossref]

4. Horn S, Figl A, Rachakonda PS, Fischer C, Sucker A, et al. (2013) TERT promoter mutations in familial and sporadic melanoma. Science 339: 959-961. [Crossref]

5. Borah S, Xi L, Zaug AJ, Powell NM, Dancik GM, et al. (2015) Cancer. TERT promoter mutations and telomerase reactivation in urothelial cancer. Science 347: 1006-1010. [Crossref]

6. Lombardo GE, Maggisano V, Celano M, Cosco D, Mignogna C, et al. (2018) AntihTERT siRNA-loaded nanoparticles block the growth of anaplastic thyroid cancer xenograft. Mol Cancer Ther 17: 1187-1195. [Crossref]

7. Zhang N, Xie Y, Tai Y, Gao Y, Guo W, et al. (2016) Bufalin Inhibits hTERT Expression and Colorectal Cancer Cell Growth by Targeting CPSF4. Cellular physiology and biochemistry. Cell Physiol Biochem 40: 1559-1569.

8. Zhou N, Fei D, Zong S, Zhang M, Yue Y (2016) MicroRNA-138 inhibits proliferation, migration and invasion through targeting hTERT in cervical cancer. Oncology Letters 12: 3633-3639.

9. Farajzadeh R, Pilehvar-Soltanahmadi Y, Dadashpour M, Javidfar S, Lotfi-Attari J, et al (2018) Nano-encapsulated metformin-curcumin in PLGA/PEG inhibits synergistically growth and hTERT gene expression in human breast cancer cells. Artif Cells Nanomed Biotechnol 46: 917-925. [Crossref]

10. Lotfi-Attari J, Pilehvar-Soltanahmadi Y, Dadashpour M, Alipour S, Farajzadeh R, et al. (2017) Co-delivery of curcumin and chrysin by polymeric nanoparticles inhibit synergistically growth and hTERT gene expression in human colorectal cancer cells. Nutr Cancer 69: 1290-1299.

11. Bagheri R, Sanaat Z, Zarghami N (2018) Synergistic effect of free and nanoencapsulated chrysin-curcumin on inhibition of hTERT gene expression in SW480 colorectal cancer cell line. Drug Res 68: 335-343.

12. Amirsaadat S, Pilehvar-Soltanahmadi Y, Zarghami F, Alipour S, Ebrahimnezhad Z, et al. (2017) Silibinin-loaded magnetic nanoparticles inhibit hTERT gene expression and proliferation of lung cancer cells. Artif Cells Nanomed Biotechnol 45: 1649-1656. [Crossref]
13. Jaiswal RK, Kumar P, Sharma A, Mishra DK, Yadava PK (2017) Proteomic identification of proteins differentially expressed following overexpression of hTERT (human telomerase reverse transcriptase) in cancer cells. PloS one 12: e0181027.

14. Kim SH, Cho KH, Kim YN, Jeong BY, Park CG, et al. (2018) Correction to: Resveratrol attenuates norepinephrine-induced ovarian cancer invasiveness through downregulating hTERT expression. Arch Pharm Res 41: 938-940. [Crossref]

15. Chatran M, Pilehvar-Soltanahmadi Y, Dadashpour M, Faramarzi L, Rasouli S, et al (2018) Synergistic anti-proliferative effects of metformin and silibinin combination on T47D breast cancer cells via hTERT and cyclin D1 inhibition. Drug Res 68: 710-716.

16. Daniel M, Tollefsbol TO (2018) Pterostilbene down-regulates hTERT at physiological concentrations in breast cancer cells: Potentially through the inhibition of cMyc. J Cell Biochem 119: 3326-3337. [Crossref]

17. Rasouli S, Zarghami N (2018) Synergistic growth inhibitory effects of chrysin and metformin combination on breast cancer cells through hTERT and cyclin D1 suppression. Asian Pac J Cancer Prev 19: 977-982. [Crossref]

18. Jahanban-Esfahlan R, Seidi K, Monfaredan A, Shafie-Irannejad V, Abbasi MM, et al. (2017) The herbal medicine Melissa officinalis extract effects on gene expression of p53, Bcl-2, Her2, VEGF-A and hTERT in human lung, breast and prostate cancer cell lines. Gene 613: 14-19.

19. Thriveni K, Raju A, Kumar RV, Krishnamurthy S, Chaluvarayaswamy R (2018) Patterns of relative telomere length is associated with hTERT gene expression in the tissue of patients with breast cancer. Clin Breast Cancer 19: 27-34.

20. Feng X, Xu X, Xiao X, Zou K, Yu W, et al. (2017) NMI inhibits cancer stem cell traits by downregulating hTERT in breast cancer. Cell Death Dis 8: e2783.

21. Dinami R, Buemi V, Sestito R, Zappone A, Ciani Y, et al. (2017) Epigenetic silencing of miR-296 and miR-512 ensures hTERT dependent apoptosis protection and telomere maintenance in basal-type breast cancer cells. Oncotarget 8: 95674-95691.

22. Ebrahimnezhad Z, Zarghami N, Keyhani M, Amirsaadat S, Akbarzadeh A, et al. (2018) Retraction note: Inhibition of hTERT gene expression by silibininloaded PLGA-PEG$\mathrm{Fe}(3) \mathrm{O}(4)$ in T47D breast cancer cell line. Bioimpacts 8: 321. [Crossref]

23. Yu P, Shen X, Yang W, Zhang Y, Liu C, et al. (2018) ZEB1 stimulates breast cancer growth by up-regulating hTERT expression. Biochem Biophys Res Commun 495: 2505 2511. [Crossref]

24. Aydin M, Sumbul AT, Camuz Hilalogullari G, Bayram S (2018) Genetic polymorphisms in human telomerase reverse transcriptase (hTERT) gene polymorphisms do not associated with breast cancer in patients in a turkish population: hospital-based casecontrol study. Cell Mol Biol (Noisy-le-grand) 64: 108-115. [Crossref]

25. Molano M, Moreno-Acosta P, Morales N, Burgos M, Buitrago L, et al. (2016) Association between type-specific HPV infections and hTERT DNA methylation in patients with invasive cervical cancer. Cancer Genomics Proteomics 13: 483-491. [Crossref]

26. Yang $\mathrm{H}$, Zhang $\mathrm{H}$, Zhong Y, Wang Q, Yang L, et al. (2017) Concomitant underexpression of TGFBR2 and overexpression of hTERT are associated with poor prognosis in cervical cancer. Sci Rep 7: 41670. [Crossref]

27. Zhang J, Ju H, Gao JR, Jiao XL, Lu Y (2017) Polymorphisms in human telomerase reverse transcriptase (hTERT) gene, gene- gene and gene-smoking interaction with susceptibility to gastric cancer in Chinese Han population. Oncotarget 8: 20235-20243.

28. Zhang YQ, Pei JH, Shi SS, Zheng J, Wang JM, et al. (2018) G-quadruplex antibody attenuates human gastric cancer cell proliferation and promotes apoptosis through hTERT/telomerase pathway. Eur Rev Med Pharmacol Sci 22: 2614-2623. [Crossref]

29. Mahfouz N, Tahtouh R, Alaaeddine N, El Hajj J, Sarkis R, et al. (2017) Gastrointestinal cancer cells treatment with bevacizumab activates a VEGF autoregulatory mechanism involving telomerase catalytic subunit hTERT via PI3K-AKT, HIF-1alpha and VEGF receptors. PloS one 12: $\mathrm{e} 0179202$.

30. Ludlow AT, Wong MS, Robin JD, Batten K, Yuan L, et al. (2018) NOVA1 regulates hTERT splicing and cell growth in non-small cell lung cancer. Nat Commun 9: 3112.

31. Yang JH, Li XY, Wang X, Hou WJ, Qiu XS, et al. (2017) Long-term persistent infection of HPV 16 E6 up-regulate SP1 and hTERT by inhibiting LKB1 in lung cancer cells. PLoS One 12: e0182775. [Crossref]

32. Sadeghzadeh H, Pilehvar-Soltanahmadi Y, Akbarzadeh A, Dariushnejad H, Sanjarian F, et al. (2017) The effects of nanoencapsulated curcumin-Fe3O4 on proliferation and hTERT gene expression in lung cancer cells. Anticancer Agents Med Chem 17: 13631373. [Crossref]

33. Chen RJ, Wu PH, Ho CT, Way TD, Pan MH, et al. (2017) P53-dependent downregulation of hTERT protein expression and telomerase activity induces senescence in lung cancer cells as a result of pterostilbene treatment. Cell Death Dis 8: e2985. [Crossref] 
34. Lin C, Qin Y, Zhang H, Gao MY, Wang YF (2018) EGF upregulates RFPL3 and hTERT via the MEK signaling pathway in non-small cell lung cancer cells. Oncol Rep 40: 29-38. [Crossref]

35. Zalewska-Ziob M, Dobija-Kubica K, Biernacki K, Adamek B, Kasperczyk J, et al. (2017) Clinical and prognostic value of hTERT mRNA expression in patients with nonsmall-cell lung cancer. Acta Biochim Pol 64: 641-646.

36. Barczak W, Sobecka A, Golusinski P, Masternak MM, Rubis B, Suchorska B, et al. () hTERT gene knockdown enhances response to radio- and chemotherapy in head and neck cancer cell lines through a DNA damage pathway modification. Sci Rep 8: 5949. [Crossref]

37. Barczak W, Suchorska WM, Sobecka A, Bednarowicz K, Machczynski P, et al. (2017) hTERT C250T promoter mutation and telomere length as a molecular markers of cancer progression in patients with head and neck cancer. Mol Med Rep 16: 441-446. [Crossref]

38. Martin SL, Kala R, Tollefsbol TO (2018) Mechanisms for the inhibition of colon cancer cells by sulforaphane through epigenetic modulation of microrna-21 and human telomerase reverse transcriptase (hTERT) down-regulation. Curr Cancer Drug Targets 18: 97-106. [Crossref]
39. March-Villalba JA, Panach-Navarrete J, Herrero-Cervera MJ, Alino-Pellicer S, Martinez-Jabaloyas JM (2018) hTERT mRNA expression in urine as a useful diagnostic tool in bladder cancer. Comparison with cytology and NMP22 BladderCheck Test(R). Actas Urologicas Espanolas 42: 524-530.

40. Huang X, Zhuang C, Zhuang C, Xiong T, Li Y, et al. (2017) An enhanced hTERT promoter-driven CRISPR/Cas9 system selectively inhibits the progression of bladder cancer cells. Molecular bioSystems 13: 1713-1721.

41. Maggisano V, Celano M, Lombardo GE, Lepore SM, Sponziello M, et al. (2017) Silencing of hTERT blocks growth and migration of anaplastic thyroid cancer cells. Mol Cell Endocrinol 448: 34-40. [Crossref]

42. Zhao X, Zheng F, Li Y, Hao J, Tang Z, et al. (2018) BPTF promotes hepatocellular carcinoma growth by modulating hTERT signaling and cancer stem cell traits. Redox Biol 20: 427-441. [Crossref]

43. Goldvaser H, Gutkin A, Beery E, Edel Y, Nordenberg J, et al. (2017) Characterisation of blood-derived exosomal hTERT mRNA secretion in cancer patients: a potential pancancer marker. Br J Cancer 117: 353-357. [Crossref]

Copyright: $\odot 2019$ Singh Z. This is an open-access article distributed under the terms of the Creative Commons Attribution License, which permits unrestricted use, distribution, and reproduction in any medium, provided the original author and source are credited. 